\title{
Máscaras, jovens e "escolas do diabo"*
}

\author{
José Machado Pais
}

Universidade de Lisboa, Instituto de Ciências Sociais

Alguns colegas meus, cujo ar circunspecto os distingue, manifestaram-me seu espanto por, em período de Carnaval, ter ousado ir para uma sala de aula com uma máscara de papelão colada à cara. ${ }^{1}$ Acharam o comportamento insólito. Na verdade, era uma aula sobre Goffman. Esbocei um sorriso irónico, pensando nas máscaras que se servem de um ar circunspecto para melhor representarem. Não há melhor representação do que aquela que é simulada com a maior das naturalidades. O "eu social", actuado em diferentes cenários da vida cotidiana, recorre frequentemente aos artifícios da representação, a máscaras mais ou menos dissimuladas que garantam uma boa actuação nos relacionamentos cotidianos (Goffman, 1993).

Um dos desafios da sociologia é desmascarar as actuações cotidianas, procurando descobrir o que elas revelam a partir do que ocultam. Se a realidade nos aparece mascarada é sensato não desprezar suas más-

* Foi mantida a ortografia de Portugal.

${ }^{1} \mathrm{O}$ episódio é relatado em meu livro Vida cotidiana, enigmas e revelações. Em Portugal, no período do Carnaval, as aulas são interrompidas apenas durante três dias. caras, embora seja certo que elas, como os mitos, não podem explicar-se por si só, como nos ensinou LéviStrauss (1979). Para desvendar o que as máscaras ocultam é necessário decifrar os seus enigmas (Pais, 2003). De que forma? Pesquisando os usos que se fazem das máscaras. É esse o desafio que lanço, tomando como referenciais empíricos diferentes cenários de actuação das máscaras, a começar pelos actos de nomeação que mascaram a realidade a partir do momento em que a nomeiam. Darei também atenção às máscaras que caracterizam os estilos juvenis, tentando vislumbrar as tramas de significado que esses estilos escondem. Finalmente, questiono a existência das máscaras no cenário de escolas que me foram retratadas como "escolas do diabo". Neste caso, a hipótese que lanço à discussão sugere que a violência protagonizada por alguns jovens nessas escolas é também uma máscara, dado ocultar formas subtis de violência a que esses jovens se encontram cotidianamente sujeitos.

\section{As máscaras sob a capa dos nomes}

As próprias realidades, pelo simples facto de serem nomeadas, são realidades mascaradas. Os nomes 
actuam como máscaras das realidades nomeadas. Com isso quero dizer que, por exemplo, quando falamos de juventude pensamos numa realidade nominal que, artificialmente, tende a esbater ou anular as distinções que de facto existem entre os jovens. À sociologia cabe desmascarar essa ilusória homogeneidade.

Não sem razão dizia Nietzsche (1980, p. 46): "todo o conceito deriva de igualarmos o que é desigual". Na verdade, nenhum jovem é integralmente igual a outro jovem. O conceito de jovem é formado por uma abstracção arbitrária de diferenças individuais. Essa abstracção dá origem à ideia de que, para além de jovens, existirá “o jovem” - suprema singularidade em que se filiariam todos os jovens, essencialismo de onde se desprenderia o conceito de juventude. Alguns equívocos educacionais passam também por uma concepção de escola dirigida a um jovem abstracto, esquecendo-se a pessoa que existe no aluno. Ora, sendo o conceito de juventude de "ordem superior", expressão que Locke utilizava para designar as "ideias compostas", o desafio que se impõe é o da sua decomposição em componentes mais elementares e significativos. Desconstruir o conceito de juventude para melhor o entender.

Quando falamos de "juventude", estamos profunda e comprometedoramente emaranhados numa complexa teia de representações sociais que se vão construindo e modificando no decurso do tempo e das circunstâncias históricas. Os escolásticos (em particular, São Tomás de Aquino) costumavam fazer uma distinção entre definições reais (definitio rei) e definições verbais (definitio nominis). Nas definições reais, o que está em causa é a essência do definido, da realidade que se nomeia. Em contrapartida, nas definições verbais o que importa é a significação dos nomes. Pois bem, quando falamos de juventude, no que mais pensamos é na significação ou representação do nome. É por essa razão que Pierre Bourdieu (1980) não hesita em propor que a "juventude não é mais que um nome" - ou seja, uma construção verbal ou representacional.

Nesse sentido, o primado da diferença entre os jovens - nomeadamente quando se confrontam as suas distintas origens e condições sociais - deve concorrer com o primado da sua pretensa unidade geracional. Se, como dizia Jorge Luís Borges (Narraciones), todo substantivo se forma por acumulações de adjectivos, a decifração do conceito de juventude passa pelo desvendar das representações que, através de sucessivas adjectivações, fazem da juventude uma realidade mascarada, por vezes uma ficção ou até mesmo um mito. Essas adjectivações rotulam os jovens ora de apáticos ora de turbulentos; de hedonistas mas também de conformistas... Isto é, de uma forma contraditória e metonímica, em que o todo é tomado pelas partes - as partes mascarando o todo e viceversa.

Muitas das máscaras nominais sob as quais se ocultam as representações da juventude são fabricações do senso comum e dos media. É o que acontece quando alguns grupos de jovens são descritos como tribos. Esse processo de etiquetagem origina realidades estereotipadas ou mitificadas. Há que questionar as máscaras que tais etiquetas representam (Pais \& Blass, 2004). Que jovens são esses que levam a etiqueta de tribo? Identificam-se eles com a etiqueta? Que propósitos e efeitos se associam ao processo de etiquetagem? Questões desse tipo podem ajudar-nos a resistir a um efeito de contaminação conceptual que, no caso de algumas culturas juvenis, nos levaria a desenvolver uma sociologia acrítica, confundindo conceitos com preconceitos.

Os jovens são o que são, mas também são (sem que o sejam) o que deles se pensa, os mitos que sobre eles se criam. Esses mitos não reflectem apenas a realidade, ajudam-na também a instituir-se como uma idealização ou ficção social. O importante é não nos deixarmos contagiar por equívocos conceptuais que confundem a realidade com as representações que a conformam ou dela emanam (Ruíz, 1995, p. 81). É que, como disse, as palavras, por vezes, mascaram a realidade, ou melhor, constroem-na à imagem das máscaras que usam para a representar. Aliás, as fases de vida e a própria idade são construções sociais. Por exemplo, entre os tuaregues - uma tribo nómada da Nigéria - não se contam os anos de vida. Se um an- 
tropólogo se dirige a algum nativo da tribo questionando-lhe a idade, este poderá responder: "30 anos". Se o antropólogo desconfia da veracidade da resposta, sugerindo que o nativo aparenta ter mais idade, este poderá responder-lhe, para o satisfazer: "Hum... talvez tenha uns 100 anos”. O que aqui está em causa não é uma incapacidade de contagem por parte dos tuaregues, mas uma indiferença em relação ao cálculo dos anos de vida. Nunca me esquecerei da lição que, um dia, um guia-mirim de Olinda (Pernambuco) me deu. Quando o questionei sobre a sua idade e manifestei a minha surpresa por um corpo tão franzino reivindicar dezassete anos, ele esclareceu-me: "Sabe, senhor? Nós aqui, em Olinda, apenas crescemos em idade".

\section{Máscaras e estilos juvenis}

Desde os tempos mais ancestrais as máscaras se afirmam nos cenários da vida cotidiana. Podemos dar o exemplo do rito da cara. Um dos deuses mais antigos da Antiguidade dava pelo nome de Porsen, deus dos mortos que zelava pelo destino dos vivos. E, claro, os vivos procuravam agradar a Porsen, participando no rito da cara. Criavam então uma representação plástica de suas próprias caras, mas deformadas segundo a figura do deus. Assim surgiram as máscaras. Depois penduravam as máscaras na "árvore sagrada" (a árvore da vida) e deixavam-nas ficar a baloiçar (rito de oscilação). Esperavam que o vento, influenciado pelo deus, ao mover as máscaras, libertasse os fluidos negativos, os destinos nefastos. Por serem ofertadas a Porsen, as máscaras passaram também a ser chamadas de persona (de onde, do latim, deriva o termo personalidade).

Embora rejeitem o estatuto de "caretas" (Pais, 2005b), os jovens não deixam também de investir em máscaras e representações. Seus estilos visuais marcam presença pela diferença: são as poupinhas nos penteados (vanguardistas), os medalhões nos casacos de couro (heavy metal), os cabelos encaracolados e rebeldes (surfistas) etc. A cara é, nesse contexto, um instrumento de representação particularmente importante. É a preocupação com maquilhagens, batons, sombras, brincos, gel, colónias, after-shaves, borbulhas, barba etc.

Como interpretar o significado dos estilos juvenis? É aqui que a perspectiva analítica do cotidiano nos pode ajudar a decifrar o significado, tantas vezes oculto, desses estilos. De que modo? Pela contextualização desses estilos e da relação de uso que os jovens têm com eles. Ao fornecer aproximações à realidade social que revelam a forma como esta é socialmente construída, a perspectiva do cotidiano toma por base de incidência os contextos vivenciais dos indivíduos que, por sua vez, iluminam ou informam os contextos sociológicos (analíticos, interpretativos, explicativos) usados pela teoria (Pais, 2003). Quando os primeiros não informam adequadamente os segundos, isto é, quando os deformam, o discurso sociológico corre riscos de se perder nos mares convulsos de tempestuosas teorias completamente desenraizadas, ou seja, com a "terra" (isto é, a realidade) à ilharga, perdida de vista.

A forma como um jovem se veste reveste-se de significado simbólico. Como sugere Spradley (1979), símbolo é qualquer objecto ou evento que se refere a alguma coisa ou, melhor ainda, todo símbolo envolve três elementos: o símbolo em si mesmo, um ou mais referentes e a relação entre símbolo e referente(s). Essa tríade é a base de qualquer "significado simbólico". A descoberta dos significados dos símbolos passa pela compreensão dos significados que esses símbolos têm para os jovens, mas vai mais longe do que isso: passa também pela compreensão do uso que eles fazem desses símbolos. Um exemplo ilustrativo: o negro do vestuário dos jovens vanguardistas ou góticos é um símbolo. Qual o significado que o negro tem para eles? Ao perguntar-lhes (Pais, 1993) por que usavam roupa negra, responderam-me: "porque gosto". O símbolo refere-se, pois, ao gosto. Mas o referente "gosto" pode também se converter em símbolo. O que representa? Qual o seu referente? Quando pedi a esses jovens que me justificassem o "gosto pelo negro", responderamme, invariavelmente, com um evasivo encolher de ombros: "porque gosto". O que significava, entretan- 
to, esse "encolher de ombros" e a reafirmação do gosto como causa e efeito de si mesmo? Aqui há que recorrer aos contextos analíticos, indirectamente informados pelos jovens mas não redutíveis, obviamente, ao que dizem.

Qualquer significado envolve, por conseguinte, símbolos e um emaranhado de outros significados. Por isso se costuma dizer que qualquer significado é referencial ou denotativo. Mas para além dos significados denotativos há também os conotativos, significados estes que incluem toda a sugestiva significância de símbolos que ultrapassa qualquer significado referencial imediato. O negro dos jovens vanguardistas ou góticos - para voltar ao exemplo referido - conota significâncias que se situam para além do significado referencial gosto. O negro é para esses jovens um símbolo que denota gosto. No entanto, esse referente é conotável com outros referentes (analíticos) dos quais os jovens não têm consciência. Não basta perguntar a esses jovens o que para eles representa o "negro". Há que averiguar a relação que o símbolo (negro) tem com outros símbolos. Por exemplo, os que se referem ao meio social em que esses jovens vivem, à forma como outros jovens se vestem etc. Só desse modo podemos descobrir que o uso do negro pode expressar um real desejo - embora não manifesto - de distinção e distanciação social (Pais, 1993).

O exemplo acabado de dar o que mostra? Que as modas ou estilos arrastam simbologias distintas. Porém, o significado dessas simbologias não é visível nem manifesto. Desse modo, não podemos cair na tentação de embarcar nas chamadas falácias descritivas que são identificadas pelo filósofo J. L. Austin (1996) quando questiona o papel dos "enunciados" circunscritos ao desempenho de uma única função: descrever ou anunciar algum facto. A "falácia descritiva" consiste em tomar como enunciados fácticos expressões "sem sentido" ou expressões que se "disfarçam" (por exemplo: um "enunciado de direito" ser tomado como um "enunciado de facto"). Ao contrário dos enunciados fácticos que imitam, as expressões de aparente "sem sentido" não descrevem nem registam nada (e não são verdadeiras nem falsas); são expressões que se realizam em sua acção e, por isso, Austin designa-as de expressões realizativas (performative utterances ${ }^{2}$ ). Realizar é o verbo usual que se antepõe ao substantivo acção. As expressões realizativas indicam precisamente a realização de uma acção que não se confunde com o mero acto de dizer algo.

O que Austin (1996) contesta é que as expressões emitidas tenham de ser necessariamente explicadas em termos dos significados dessas expressões (por exemplo: palavras, grafitos, imagens). Por isso nos propõe uma teoria fundamentada nas "forças ilocutórias" para ultrapassar os problemas colocados pelo uso locutório. Essas forças ilocutórias integram o contexto em que se produz o acto locutório. Para além dos actos locutórios (locucionary acts) e ilocutórios (illocucionary acts), Austin desenvolve ainda o conceito de actos perlocutórios (perlocutionary acts). Frequentemente, dizer algo, segundo Austin, produzirá certas consequências ou efeitos sobre os sentimentos e acções do auditório. E é possível que, ao dizer algo, o façamos com o propósito, intenção ou desígnio de produzir tais efeitos. Estamos, nesse caso, perante actos perlocutórios.

Por exemplo, os grafitos são expressões que devem ler-se por referência às forças ilocutórias (de contexto) ou aos efeitos (perlocutórios). Entre os writers (grafiters) o que conta são os efeitos perlocutórios que provocam uma avaliação da expressão artística em função de efeitos estéticos apreendidos por quem domina essa arte de rua. Entre os grafiters aparece muitas vezes embaralhado o que se diz com o que se mostra (Austin, 1996, p. 144). O mesmo acontece com algumas expressões da cultura punk. Por exemplo, o que representa a suástica usada frequentemente pelos punks? Segundo Caiafa (1989), representa uma negação: a negação de que o seu uso se liga ao discurso que ela representa; a ostentação de um símbolo (suástica) como negação da ideologia que

${ }^{2} \mathrm{Na}$ classificação de Austin de speech acts, o performativo é caracterizado por nada revelar no dizer (por exemplo: "Bom dia, como está?"). 
lhe aparece associada. Mas a compreensão desse uso é impossível ao mero nível locutório. É aos níveis ilocutório e perlocutório que verificamos que o símbolo é desinvestido de sua significação. Da mesma forma, outras expressões da cultura punk que são símbolos de violência não legitimam a identificação da cultura punk com uma violência gratuita. Esses símbolos não são ostentados como uma bandeira. Eles são apenas usados como actos locutórios: botas, fuzis, capacetes, camuflagens, máscaras (Caiafa, 1989).

Os estilos juvenis actuam frequentemente como máscaras, da mesma forma que as culturas juvenis podem representar "soluções" a problemas e contradições relativamente às circunstâncias que os jovens vivem. Hebdige (1979) mostrou como o vestuário adornado dos teddy boys não tinha, nos anos de 1970, o mesmo significado que tivera nos anos de 1950. E, não obstante, em ambas as épocas os jovens adulavam ídolos comuns (Elvis, Eddi Cochrane, James Dean), usavam os mesmos encaracolados de cabelo e detinham, aproximadamente, a mesma posição social. Os conceitos de conjuntura e especificidade - cada subcultura, argumenta Hebdige, representa um distintivo momento, uma particular resposta a um particular conjunto de circunstâncias - são, portanto, indispensáveis no estudo das culturas juvenis.

É nesse sentido que o estilo de vestuário dos teddy boys aparece nas décadas de 1950 e 1970, respectivamente, como solução ou resposta a diferentes conjunturas que os posicionaram diferenciadamente no que respeita a outras formas culturais de existência (culturas de emigrantes, culturas geracionais, culturas dominantes etc.). Os teddy dos anos de 1950 haviam marcado uma nova tendência e, embora minoritária, sua cultura foi bastante difundida pela imprensa da época como sintomática de um iminente declínio da Grã-Bretanha. Em contrapartida, o ressurgimento dos teddy na década de 1970 é publicamente visto como legítimo, como uma virtual instituição no meio da confusão marcada por uma série de modas juvenis, dentre as quais a mais chocante talvez tivesse sido a dos punks. Os novos teddy boys eram olhados com tolerância, com cumplicidade ou nostálgica afeição (alguns dos novos teddy terão tido pais teddy).

Com efeito, o reaparecimento dos teddy boys nos anos de 1970 fez renascer entre alguns elementos das velhas gerações a lembrança de um tempo sentido como surpreendentemente remoto e de maior segurança (nomeadamente económica). Porém, paradoxalmente, os teddy que originariamente (anos de 1950) haviam fornecido "dramáticos" sinais de mudança acabaram, nos anos de 1970, por representar um "símbolo de continuidade". Em suma, os teddy boys representaram duas "soluções distintas" em diferentes condições históricas e atmosferas ideológicas. A própria pompa no trajar e a agressividade sexual tinham significados diferentes nos dois períodos. Nos anos de 1950, o alvo a abater era o mundo apático e cinzento onde os "meninos-bem" jogavam ping-pong. Nos anos de 1970, a pompa e os estereótipos exóticos herdados da velha geração dos teddy eram considerados reaccionários, nomeadamente pelos operários vivendo em situação pouco desafogada (Jefferson, 1976).

Como vemos, os estilos aparecem frequentemente como máscaras cujo significado depende dos contextos cotidianos de uso. Os mesmos símbolos culturais podem ter significados distintos. O que importa é decifrá-los, tendo presente que, se são pouco transparentes para o pesquisador, muito mais o são para os comuns portadores desses signos. Para Hebdige (1979), o significado dos estilos culturais é amortalhado pelo senso comum que validaria e, simultaneamente, mistificaria as formas ideológicas que os incorporam. Nessa ordem de ideias, os estilos seriam tão opacos quanto as relações sociais que os produziriam e que neles acabariam por se ver representadas. Em toda a "significação" encontraríamos, assim, uma dimensão ideológica e em todo o estilo, pela mesma ordem de ideias, uma distorção da realidade. Por um lado, pelo facto de a ideologia (nomeadamente na forma de senso comum) mascarar a realidade; por outro lado, por efeito de os estilos, sendo portadores de ideologia, aparecerem como refractores dessa realidade mascarada. 
Vejamos qual a metodologia proposta por Hebdige para descobrir ou decifrar a carga ideológica dos estilos. Prioritariamente, propõe a decifração dos códigos pelos quais o "significado" dos estilos se organiza. No caso das subculturas juvenis, o significado desses estilos (roupas, maquilhagens, penteados etc.) é interpretado por Hebdige como uma forma de resistência às culturas dominantes. Para ele, como para Barthes (1972) - sua fonte de inspiração teórica -, há uma espécie de ideologia anónima e dominante que penetra em todos os meandros da vida social e se inscreve nos mais mundanos rituais da vida cotidiana, enquadrando todos os sistemas de interacção social. Nessa ordem de ideias, os estilos juvenis mais audaciosos funcionariam como uma forma de resistência às culturas dominantes e hegemónicas, contradizendo o mito do "consenso social" que a ideologia dominante, segundo Hebdige, procura sustentar.

Então, os estilos juvenis poderiam ser interpretados como uma reacção dos jovens resultante de sua situação de marginalidade ou subalternidade. À falta de protagonismo no mercado de trabalho sucede-se sua afirmação no mercado de consumo. À perda de capitais sociais tradicionais respondem os jovens com investimentos em capitais sociabilísticos. À falta de identidades profissionais os jovens instrumentam identidades fabricadas em torno das mais diversificadas imagens e estilos. Nessa linha de argumentação, os estilos poderiam ser lidos como "rituais de resistência", violações simbólicas à ordem social dominante. Eles arrastariam uma função latente: a de expressarem ou "solucionarem" - embora mágica ou simbolicamente contradições "ocultas" ou "indecifradas" da cultura operária (Cohen, 1972; Clarke, 1976).

As hipóteses anteriormente descritas são extrapoláveis. Numa sociedade marcada pelo "marketing de imagens", as próprias imagens podem transformar-se em "armas de resistência" (Ewen, 1988). Assim, os jeans remendados e gastos ou o vestuário em "segunda mão" podem representar uma rejeição do ethos dominante do moderno consumismo; os cortes de cabelo dos jovens africanos rap podem ser um símbolo de convivência étnica ou "soluções estéticas" a uma plu- ralidade de problemas criados por ideologias racistas (Mercer, 1987); a apropriação, por parte das mulheres, de vestuário com corte masculino pode simbolizar um desejo de emancipação das mulheres.

As contradições de classe seriam, por conseguinte, exibidas através de "estilos" e magicamente solucionadas ao nível das aparências. E é por essa razão que os símbolos aparecem revestidos de uma capa $m i$ tológica (também aqui a presença de Barthes é notória...) cumprindo uma função vital de "naturalização" ou "normalização" do domínio hegemónico de determinadas culturas (dominantes). No trilho interpretativo que temos vindo a seguir, as "poupinhas" ou os cortes de cabelo, os medalhões ou as vestimentas exóticas juvenis transportam significados secretos que expressam, em código, uma forma subtil de resistência à ordem dominante que, aliás, não deixa de garantir a continuidade de formas de subordinação cultural.

Não interessa agora comprovar ou refutar as teses de Hebdige, Stuart Hall, P. Cohen, John Clarke, Tony Jefferson e outros sociólogos do Centre of Contemporary Cultural Studies (CCCS) - teses que, aliás, são discutíveis, na medida em que a hipótese da "resistência" pode ser, ela própria, um artefacto teórico que mascara o simples desejo de existência. Porém, os trabalhos desenvolvidos pelos sociólogos de Birmingham alertam-nos para um ponto essencial: os “estilos juvenis" encontram-se cheios de significação, embora esta apareça frequentemente oculta, resistindo à sua desvelação. Eis o desafio que se coloca à sociologia das culturas juvenis: o de, na linha teórica defendida por Barthes em suas Mitologias, procurar decifrar as mensagens ocultas e codificadas nas cintilantes aparências dos estilos, de modo que se descubra o que obscuramente representam ou o que ocultam, mesmo quando esses são chamados a solucionar, "magicamente", o que ocultam.

\section{"Escolas do diabo": quem veste a pele do mafarrico?}

E, nas escolas, haverá também lugar para as máscaras? Em Portugal temos algumas "escolas do dia- 
bo" - assim foram designadas por alguns professores, tal a imagem de violência que lhes aparece associada. As "escolas do diabo", que em linguagem tecnocrática são classificadas como "escolas de risco", revelam uma particularidade digna de registo. A maioria é frequentada por jovens provenientes de bairros degradados. Como corre a ideia, bem apressada, de que há nestes bairros uma predominância de famílias de origem africana e cigana, ocorrem duas outras particularidades não menos dignas de registo: uma delas vinca a associação da violência aos jovens de origem africana e cigana; a outra faz com que, de modo geral, os professores fujam dessas escolas como o diabo da cruz.

Por que razão muitos professores recusam leccionar nestas "escolas do diabo"? Evidentemente - a razão salta à vista - porque elas não são nada fáceis, como não são fáceis de lidar alguns dos alunos que as frequentam. Numa carta aberta ao presidente da República recentemente divulgada na internet, um professor queixava-se dos seus alunos:

Entram na sala de aula aos berros e aos encontrões, trazem vestidas camisolas interiores cavadas, cheiram a suor e a outras coisas e têm os dentes em mísero estado [...]. Não fazem distinção entre o recreio e o interior da sala de aula onde entram de boné na cabeça, headphones nos ouvidos continuando as conversas que traziam do recreio. ${ }^{3}$

A evidência que salta à vista é a indisciplina desses alunos - sendo menos evidente mas não menos real a incapacidade dos pais destes em os educar convenientemente. Mas não é apenas sobre evidências que "saltam à vista" que vale a pena reflectir. Importa também questionar o modo como essas evidências saltam à vista e aquelas outras realidades que, por menos evidentes ou visíveis, não deixam de se constituir em realidades sociologicamente problemáticas. De facto, nas escolas ditas do "diabo", a realidade da violência não se restringe aos comportamentos de indisciplina ou à que

${ }^{3}$ Carta de um professor de Ílhavo, de 22 de outubro de 2007. é contabilizada nas estatísticas policiais. A recusa de alguns professores em leccionar nessas escolas remete-nos para outro género de violência: uma violência de encher a cabeça. Há professores - não todos, evidentemente - que metem na cabeça uma ideia fixa: escola que tenha "pretos" e "ciganos" é uma escola dos "diabos". Como a cabeça é usada não apenas para acolher ideias fixas mas também para, a partir delas, gerar corolários e deduções compatíveis, surge a possibilidade de alguns professores racionalizarem a escolha das escolas, optando por ambientes sossegados, isto é, livres de pretos e ciganos. Quando algum aparece, há logo a tendência para o olhar como "fonte de problemas", desse modo originando-se outra forma de violência, a da presunção.

Investigações desenvolvidas em contexto escolar multicultural, ao nível do $1^{\circ}$ ciclo do ensino básico, sugerem que entre muitos professores há um "desagrado no trabalho com classes multiculturais, com presença de alunos negros e ciganos [...]. O que efectivamente constrangia os docentes era a cor $-\mathrm{o}$ negro -, como marca visivelmente definidora de estereótipos e de preconceitos enraizados" (Silva, 2005, p. 3). Outros professores, no entanto, têm dificuldades em reconhecer a existência de racismo nas escolas. Assegurando que "não há racismo", formulam uma espécie de profecia que esperam poder cumprirse por si mesma, na medida em que acreditam que o que é negado não existe. Certamente há jovens negros e ciganos que são violentos e delinquentes, mas não é certo que todos o sejam. Curiosamente, o próprio discurso sociológico é permeável a esta violência de encher a cabeça quando, por exemplo, tende sobretudo a explicar por que razão os jovens negros, ciganos ou pobres inevitavelmente delinqúem. Por que não procura a sociologia averiguar por que muitos deles não delinqúem, apesar das carências económicas em que vivem?

Quando nos questionamos sobre as origens da violência juvenil, não é invulgar encontrarmos na imprensa ou na literatura sociológica noções como: desequilíbrios afectivos, distúrbios emocionais, orgulho perverso etc., ou seja, noções que instituem os 
actos de violência como traços de individualidade. Frequentemente, dos "actos" passa-se às "maneiras de ser" e estas são mostradas como não sendo outra coisa do que os próprios "actos de violência". Implicitamente, surge o reconhecimento de que um acto de violência cometido por um jovem negro ou cigano resulta da "maneira de ser" das suas etnias de pertença. Nesse julgamento, o que se pune não é o acto de violência em si, mas a imagem preconcebida do jovem delinquente: ou porque usa brinco na orelha, ou porque tem um corte de cabelo exótico, ou porque exibe uma tatuagem, ou pela simples cor da pele (Foucault, 2001).

Anedotas que circulam entre professores do ensino secundário caricaturam tentativas pontuais de adaptação dos conteúdos programáticos às supostas realidades vividas por esses alunos, tidos como "problemáticos". O interesse sociológico desse anedotário permite colocar a descoberto as "comunidades imaginadas" (Anderson, 1991) em que alguns professores alojam os seus alunos. Basta atentar em alguns enunciados de problemas de matemática jocosamente recomendados para as "escolas do diabo".

O Joãozinho tem uma metralhadora AK-47 com carregador de 80 balas. Por cada rajada Joãozinho gasta 13 balas. Quantas rajadas poderá disparar até descarregar a arma?

Rui é chulo e tem três prostitutas a trabalhar para ele. Cada uma delas cobra 40 euros dos quais 30 euros entrega ao Rui. Quantos clientes terá que atender cada prostituta para poder comprar ao Rui a sua dose diária de crack no valor de 100 euros?

Januário comprou 200 gramas de heroína que pretende revender com um lucro de $20 \%$ à custa de mistura com giz. Qual é a quantidade de giz que terá de adicionar?

Uma lata de spray dá para pintar uma superfície com $3 \mathrm{~m}^{2}$. Uma letra grande ocupa uma área de $0,4 \mathrm{~m}^{2}$. Quantas letras grandes poderão ser pintadas com 3 latas de spray?
Essa violência da presunção, manifestação típica da violência de encher a cabeça, frequentemente resulta da tendência em amarrar as condutas indisciplinadas dos jovens às suas pertenças étnicas o mesmo acontecendo com o insucesso escolar (Sebastião, 2001; Batalha, 2004). Essa etnicização da violência e do fracasso escolar alimenta e é alimentada por representações sociais de natureza metonímica, uma vez que a parte é confundida com o todo e vice-versa. O falso pressuposto é o de todos os jovens "ciganos" ou "negros" serem vistos como violentos ou inadaptados, enquanto os "brancos" não o são. A hipótese que aqui se levanta é a de essa representação social se ir empolando à medida que se vai projectando, embora, em abono da verdade, nem todos os professores alinhem por essa cindida color-line.

Outra manifestação da violência da presunção resulta da imputação da burrice feita na base das aparências ou da intuição. Manifestações dessa violência encontram-se em atitudes de pais e professores que vaticinam futuros sombrios para alguns jovens: “este não vai chegar longe!”. Facilmente, muitos desses jovens conformam-se com a predição que os leva à perdição. Interiorizam o estatuto que lhes é atribuído e os resultados escolares não tardam em materializar ou ratificar as profecias: tornam-se tal qual os descrevem. A máscara de "burro" com que os pintam é tomada por esses jovens como real, ao mesmo tempo em que desinvestem da escola, assumindo que não gostam mesmo dela.

Ao avaliarem os seus alunos em função das expectativas preconcebidas que têm sobre eles, tais professores convertem a avaliação escolar na confirmação das suas próprias profecias. Outros há que não dão mostras de atentarem nas carências dos seus alunos, embora essa ignorância raramente seja posta em causa. Por camuflar realidades que finge não ver, essa violência subtil - da vista grossa - dificilmente é reconhecida, embora seja sentida por muitos alunos e percebida por alguns professores. Numa reportagem sobre violência escolar, uma professora confessou a um periódico: "muitas vezes não conseguimos che- 
gar ao seu sofrimento". ${ }^{4}$ Possivelmente há muros na comunicação entre professores e alunos "inadaptados", muros que colocam em risco as possibilidades educativas. Um professor de "terreno" - não dos muitos que falam de pedagogia sem qualquer experiência de ensino - sustenta: "Todas a escolas deveriam ser espaços [...] de múltiplas interacções, comunicação, cooperação, partilha... Sabemos que não é bem assim. As escolas são, quase sempre, espaços de solidão" (Pacheco, 2003, p. 10).

A esse ponto chegados, impõe-se dizer que todas essas violências são de ordem e natureza diferentes (Actas..., 2001; Costa \& Vale, 1998): num caso estão em jogo estereótipos simbólicos que se traduzem numa estigmatização social; noutro caso estamos perante uma violência material traduzida em roubos, agressões físicas etc. Esses diferentes tipos de violência apenas têm em comum o facto de poderem ser exercidos num mesmo palco - o da escola. Em todas as escolas? Obviamente que não. Mais frequente ou visivelmente, nas chamadas "escolas do diabo". A possibilidade de alguns alunos serem vítimas, na escola, de uma violência simbólica não implica a desculpabilização daqueles que, efectivamente, praticam actos violentos traduzidos em danos físicos, materiais ou outros. Apenas se sugere que as malhas com que se tece a "violência escolar" são de textura heterogénea e de urdiduras bem mais complexas do que se possa supor a uma primeira aproximação. É lícito admitir que essas distintas ordens de violência apareçam entrelaçadas, embora não pareça defensável uma imputação causal de sentido unívoco ou determinístico. Como quebrar esse aparente ciclo vicioso? Sendo as escolas instituições "educativas", qual seu papel nesse encadeamento de acções, reacções e retroacções?

A criança que recebe o apodo de "violenta" acumula, provavelmente, o ódio do estigma ao ónus da

${ }^{4}$ Depoimento de uma professora da Escola Básica 2/3 Pedro de Santarém, em Lisboa, sobre o problema da indisciplina escolar. Diário de Notícias, de 9 de setembro de 2002. marginalidade em que vive. Com efeito, o internamento de menores em instituições tutelares pouco se deve à "suspeita de factos ilícitos" ou a "condutas desviantes" (mendicidade, prostituição, vadiagem ou libertinagem). Em Portugal, o grosso dos motivos que determinam a actuação dos tribunais sugere uma clara vulnerabilidade dessas crianças: "maus-tratos, abandono, desamparo, negligência" (estatísticas oficiais da Justiça). Os relatórios consultados sobre as "escolas de risco" da Direcç̧ão Regional do Ensino de Lisboa - e também os dados do Gabinete de Segurança do Ministério da Educação - sugerem que os principais factores da violência escolar são exógenos à escola. Esta é vulnerável à violência social que sofre do exterior (bairros degradados, pobreza extrema, dramas familiares, tráfico de droga, prostituição, pequenos grupos de assaltantes etc.). Daí a ideia corrente de os bairros "problemáticos" desenvolverem uma cultura hostil em relação à escola. Por vezes assim acontece, embora de modo não generalizado. Como quer que seja - porque as condições miserabilistas em que vivem alguns jovens desses bairros têm, também, uma incidência manifesta sobre seu comportamento escolar -, muitos dos problemas que eles vivem na escola não existiriam se as suas condições de vida fossem outras. Nomeadamente, se as políticas de alojamento não tivessem suscitado uma guetização de famílias, muitas delas emigrantes, vivendo em condições deploráveis. Frequentemente - mas não de modo inevitável ou generalizado -, "a escola é vista como um território onde se desafia a autoridade e o poder que emana de fora do bairro (professores, polícia, estado, 'portugueses')" (Batalha, 2004, p. 316).

A esse respeito, há pelo menos duas posições que se podem contrastar no campo das políticas educativas. Uma delas, ao considerar a ênfase exógena da "violência escolar", sugere que a escola nada pode fazer para remediar uma situação que é eminentemente estrutural e gerada fora dela. Pela mesma ordem de ideias, os professores também se sentiriam impotentes para resolver problemas que lhe são alheios - desse modo se justificando que alguns fujam das "esco- 
las do diabo" como o mesmo da cruz. É uma estratégia de debandada e ponto final. Noutra posição, o reconhecimento do peso avassalador dos factores exógenos à escola, no que concerne ao desempenho dos alunos que a frequentam, não impede a possibilidade de alguns desses jovens poderem ter sucesso escolar nem legitima que a escola se ilibe de suas responsabilidades.

Para alguns defensores dessa segunda posição, os rituais de resistência à escola protagonizados por jovens que desafiam os códigos legitimados e credenciados por ela seriam expressão de contradições não apenas exógenas mas também endógenas ao sistema de ensino (McLaren, 1992). E isso aconteceria por quê? Porque - é o argumento avançado - o sistema de ensino não se mostra capaz de comunicar com culturas diferentes do seu padrão "normal". Para os defensores dessa posição, a integração escolar, de natureza assimilacionista, depende da capacidade de os jovens se adaptarem ao desempenho de um padrão normalizado. Chegam à escola diferentes - porque têm origens sociais e memórias culturais diferentes , mas a escola pretende à força torná-los iguais, caindo na falácia de identificar democratização com massificação e homogeneização. Aliás, não é por acaso que a crise da escola é frequentemente vista como reflexo da sua massificação (Mónica, 1997; Magalhães \& Stoer, 1998; Boudon, Bulle \& Cherkaoui, 2001). Uma possível razão? O padrão-norma não respeitaria as individualidades, fechando-se em relação à diversidade (Sebastião, Alves \& Campos, 2003, p. 38-39). Na lógica dessa argumentação, os mesmos jovens que são olhados como diferentes (pretos ou ciganos) passariam agora a ser avaliados como iguais, segundo o "padrão-norma".

Esse absolutismo modal afectaria de modo muito significativo todos aqueles que se afastassem da mediania: não apenas os "herdeiros" (Bourdieu \& Passeron, 1964; Fonseca, 2003) de capitais familiares (sociais e culturais) que, antes da democratização do sistema de ensino, beneficiavam-se da natureza "burguesa" do sistema escolar, como os actuais "deserdados" (Dávila, Ghiardo \& Medrano, 2005). Nos anos de 1960 e 1970, colocava-se em causa a capacidade do sistema escolar em reduzir as diferenças sociais, ao converter-se num mecanismo que mantinha e aprofundava a distância entre as classes sociais. Actualmente, discute-se a incapacidade do sistema do ensino de "respeitar as diferenças" - tanto a dos "herdeiros" quanto as dos "deserdados". Por exemplo, teme-se que as "elites" possam ser engolidas pela medianização que a padronização promove. Nem sempre os defensores das "elites" têm sido bem compreendidos, como se fossem adversários da "democratização do ensino". Esta não é incompatível com o "elitismo", defendem os que o elogiam. Se há "desportistas de elite", "tropas de elite", "artistas de elite", por que razão não aceitar "cientistas de elite", "professores de elite", "alunos de elite" (Javeau, 2000)? Por fugirem ao padrão normal, os alunos "fora da média" são por vezes olhados como problemáticos e avaliados em função de representações pré-construídas e estigmatizantes. Assim acontece com os rotulados de "superdotados", por isso aconselhados a ter acompanhamento psicológico, tal qual acontece com aqueles outros jovens que fogem ao "padrão normal" pela negativa, isto é, os "deserdados" de capitais escolares, frequentemente rotulados de "inadaptados" e que alimentam as estatísticas do insucesso escolar. Esses paradoxos têm originado críticas quanto às dificuldades da escola em lidar com a "diferença" (Dayrell, 2001).

Há jovens - negros ou ciganos - que entram numa escola ideologicamente orientada pelo princípio da igualdade de oportunidades, mas, na realidade, eles são muitas vezes tratados como diferentes quando deveriam ser tratados como iguais. É o que acontece ao serem olhados de lado, sendo desse modo estigmatizados. Outras vezes, esses jovens gostariam de ser compreendidos na sua diferença, mas acabam por ser tratados como iguais. É o que acontece quando não há uma mínima preocupação com as suas carências económicas ou afectivas. Quando as diferenças que fazem de cada aluno um ser humano não são levadas em linha de conta ou sempre que, por razões não justificadas ou de simples presunção, se é tido como igual mas olhado como diferente, pode surgir 
entre quem é alvo de discriminação ou abandono um sentimento de solidão expresso em revolta.

Esse sentimento de revolta poderá surgir, potencialmente, entre alunos que não reconhecem a escola como sua. Perscrutarei essa hipótese a partir de um estudo de caso constituído por uma das chamadas “escolas do diabo", localizada nos subúrbios de Lisboa, tomando por alvo de reflexão os alunos ciganos.

Entre os que abandonaram a escola, as recordações que dela têm não são boas. Há queixas dirigidas a professores por "ralharem", "mandarem bocas", "darem castigos", "passarem muitos trabalhos de casa". É possível que entre estes alunos haja muitos casos de desleixo, preguiça, desmotivação. No entanto, entre as raparigas os deveres escolares raramente eram realizados também em razão das tarefas domésticas e dos cuidados dirigidos aos irmãos menores, o que repercutia negativamente no sucesso escolar. Em contrapartida, as jovens que abandonaram a escola reconhecem a atitude agressiva que tinham na escola, embora como reacção de revolta ante atitudes de rejeição, em particular por parte de colegas que recusavam brincar com elas ou emprestar a corda de saltar, a bola etc.

As miúdas tinham medo de estar ao pé de mim. Se não me dessem o que queria andava à porrada com elas. Se elas não me chamavam para brincar, se elas tivessem uma coisa e não me dessem a mim, roubava a corda (de saltar) ou a bola. Elas iam dizer à professora, a professora dizia ao director. Uma vez fiquei um mês expulsa. Até aos rapazes eu batia. Aos rapazes era dentadas que eu dava. Eles choravam.

Como interpretar esses comportamentos das crianças ciganas? Entre múltiplas hipóteses, não são de desconsiderar possíveis represálias a atitudes de rejeição, como sugerido no depoimento transcrito. É também provável estarmos perante a expressão de um orgulho ferido que as impele a não se deixar subordinar a valores estranhos que a escola lhes pretende inculcar. Entre os ciganos, é ainda possível que o analfabetismo tenha funcionado como suposto factor de protecção contra agressões de outras culturas veicu- ladas pela escola e suas aprendizagens (Liégeois, 1998, p. 16). Entre os contos populares ciganos circula o seguinte:

Era uma vez um rei que tinha o alfabeto cigano. Embrulhou-o numas folhas de couve, porque naquele tempo não tínhamos estantes para pousar as coisas, e adormeceu até a primavera. Veio um burro beber água e comeu as folhas de couve. (Tong, 2002, p. 207)

Por aqui vemos que a reivindicação da diferença em nome da "tradição" nem sempre se conjuga com emancipação. Há famílias ciganas que continuam a desconfiar da formação que a escola possa dar aos seus filhos; preocupam-se, sobretudo, com a deformação que lhes possa dar, enchendo-lhes as cabeças com ideias avessas às suas tradições e, por consequência, desencaminhando-os das famílias. As causas aparentes do insucesso escolar (falta de interesse, absentismo, violência, recusa em estudar...) podem ser, afinal, efeito de uma inadaptação profunda à escola que está longe de ser uma inadaptação individual. Nesse sentido, convém não tomar os efeitos como causas do fracasso escolar. Para muitos ciganos a escola é sempre a escola dos outros; como a polícia é a polícia dos outros; ou os hospitais são os hospitais dos outros. Há ciganos que só em caso extremo aceitam a hospitalização de algum familiar e, se isso acontece, os mais chegados fazem questão de acompanhar o enfermo, mesmo que para o efeito tenham de improvisar um acampamento junto do hospital. O mesmo se passa em relação à escola. As crianças ciganas são educadas no temor ao que lhes é estranho. A escola forma parte desse mundo estranho, onde coisas estranhas lhes são ensinadas:

\footnotetext{
Acho que a escola deveria ser diferente. As escolas são prisões e as crianças ciganas não aguentam estar lá fechadas por muito tempo. (Sousa, 2002, p. 4)
}

Estamos perante jovens convidados a participar num reino (a escola) onde frequentemente a sua etnicidade - imputada ou assumida - é convertida em 
fracasso escolar (Enguita, 1996). O seu absentismo é uma forma de evitarem a "inadaptação" à escola, por eles vista como "prisão". Em contrapartida, para a administração escolar o absentismo serve para desculpar o fracasso da escola em lidar com os jovens ciganos. Na confluência desses dois movimentos, as identidades são sacralizadas, hipostasiadas em sistemas monobloco, e como tal reificadas, exibidas, glorificadas ou rejeitadas.

É possível que o comportamento rebelde de algumas crianças corresponda a uma oportunidade de afirmação compensatória de um contrapoder relativamente àqueles que têm supremacia escolar na sala de aula. No recreio ou à saída da escola, principalmente entre os rapazes, surgem os inevitáveis ajustes de contas. Um dia, uma professora que entrevistei, de uma escola primária frequentada por crianças ciganas, abriu a gaveta da sua secretária mostrando-me uma apreciável colecção de navalhas apreendidas. Por que trazem as navalhas para a escola? Possivelmente, elas são armas de rejeição à submissão da cultura da escola, através da ritualização de uma agressividade simbólica que se emblematiza como própria da "cultura cigana”. A afirmação da identidade requer reconhecimento por parte dos demais. Existir também quer dizer ser percebido e reconhecido como distinto. Quanto mais negado, ignorado ou reprimido se é, mais necessário se torna afirmar a existência - para os outros e para si mesmo. Nesse sentido, as navalhas ciganas não são apenas armas de intimidação. Independentemente da ilegitimidade do seu porte, são também instrumentos de significação simbólica que denunciam tanto a estrutura superficial de confronto entre alunos com posições sociais distintas quanto a gramática profunda de reclusões étnicas.

As navalhas ciganas não são trazidas para a escola com o objectivo premeditado de ferir ou matar. A simbologia da navalha pode ser entendida como uma mediação que capacita o jovem cigano a moldar a realidade. Como todos os símbolos, o da navalha arrasta um poder conotativo pelo próprio facto de os símbolos serem multivalentes, incongruentes, polissémicos, fendentes. A exibição da navalha tem esse poder mágico de fazer circular visões complexas do que ela pode representar. A própria apreensão da navalha não esgota a capacidade que ela tem de, mesmo guardada na gaveta da secretária da professora da escola, condensar a representação dos muitos golpes e diabruras que poderia causar. Os símbolos têm esse poder de estruturar a imaginação e proclamar ou emoldurar a desordem, assim como a ordem, invocando um excesso de significantes.

A professora que zelosamente guarda as navalhas na gaveta da sua secretária contou-me que, durante o tempo de recreio, o que as crianças ciganas mais gostam de fazer é subir ao telhado da escola, como se andassem em busca de tesouros escondidos. $\mathrm{Na}$ verdade, confessou-me, procuram ninhos de pássaros. O telhado da escola é ressignificado pelas crianças ciganas. De função de coberta, o telhado transforma-se em superfície de descoberta, como se nesse processo de ressignificação as crianças nos quisessem dizer que o prazer da aprendizagem se passa fora do que ocorre dentro da sala de aula. A aventura vivese no telhado, com o céu por perto, à ilharga do inferno da aula. Talvez se possa dizer que o conhecimento de telhado é epistemologicamente diferente do conhecimento de sala de aula. Ele é feito de audácia, de risco, de curiosidade, de aventura, de um prazer de descoberta provavelmente diferente do conhecimento de sala de aula, quando reificado através de retóricas infladas, no seu distanciamento e abstracção do mundo vivido, do mundo real. Que fazer dos miúdos que, violando as regras costumeiras do sistema escolar, descobrem o prazer da descoberta no telhado da escola? Deixá-los vadiar pelo telhado a seu bel-prazer, numa lógica de "queremos lá saber"? Sujeitá-los à humilhação da palmatória ou de outros castigos físicos e psíquicos? Ou, mais drasticamente, instaurar-lhes processos disciplinares expulsando-os da escola?

Talvez o problema da disciplina e da ordem tenha vindo a ser mal equacionado. Ou talvez nem sequer seja problematizado quando é subsumido numa sobrevalorização de constrangimentos “étnicos”. Nada ou pouco se tem pensado sobre o sentido da organização que parte do caos em direcção à ordem. Para 
que a criança perceba o sentido da ordem, provavelmente é necessário que ela entenda o significado do caos. Se a criança tiver presente uma informação já elaborada ou sentenciada ("não podes ir para o telhado!') não vai poder tão facilmente compreender o seu significado. O mais que irá conseguir é memorizar essa informação e, em último caso, rejeitá-la ou assumi-la como algo que "tem de ser". Quando, astutamente, a directora da escola propôs às crianças ciganas que não manuseassem os pequenos pássaros (alguns morriam de tantos solavancos) e, antes, cuidassem da sua alimentação, para cujo efeito providenciou uma gaiola, todos os dias as crianças passaram a trazer de comer às aves (bolachas, pão esfarelado etc.), pois lhes tinha sido dada uma responsabilidade: a de cuidarem dos pássaros, tarefa a que se dedicaram com entusiasmo e empenho. Até que um dia descobriram que não fazia sentido manter os pássaros presos na gaiola, como eles próprios presos se sentiam na sala de aula. $\mathrm{O}$ exemplo dado sugere que, mesmo quando a celebração cega da etnia tende a expulsar os alunos da escola, há professores com artes de os cativar.

Em suma, a agressividade das crianças ciganas pode considerar-se "expressão de um mecanismo de protecção" (Liégeois, 1998, p. 114) contra atitudes (reais ou supostas) de rejeição. Não se trata apenas de uma rejeição administrativa (exigência de documentação, certificado de residência, boletim de vacinas); estamos também perante uma rejeição social, quando na sala de aula são colocadas à parte, olhadas de lado. O conformismo silencioso de alguns professores, que se traduz num encolher de ombros ("Que fazer? São ciganos!"), apenas os incita à retaliação. Numa solidão murada de silêncio, as crianças ciganas interiorizam as acusações depreciativas de que são alvo, acabando por assumir o estigma. Este, por ser socialmente produzido, pesará de tal forma que as acusações e censuras que são dirigidas às crianças acabam por consolidar a identificação com o estigma, todos elas aparecendo como produtos da mesma mácula. Nos dicionários correntes da língua portuguesa, o próprio termo "cigano" aparece identificado como sinónimo de trapaceiro, ladino, traficante de mercadorias subtraídas aos direitos, avaro, impostor etc. Nas feiras que percorri em busca dos seus modos de vida, deime conta de como nos próprios pregões transparece a força de um estigma social interiorizado, embora exteriorizado de forma irónica: "Escolham, escolham! Cinco euros! Não tem defeito! Não tem defeito!”; ou "Dez euros cada peça! Foi roubado ontem, foi roubado ontem!”. O estigma cria repulsa e exclusão mas recria também sentimentos de pertença e de inclusão entre os que se sentem estigmatizados.

Os sentimentos de "orgulho" de pertencer a uma etnia ou os desejos fantasiados de poder pertencer a outra etnia diferente têm sido estudados pela psicologia. No caso das crianças ciganas, há dados de investigação que apontam o desejo de as crianças mais novas (6 anos) pertencerem a outra etnia, o mesmo não acontecendo com as crianças mais velhas (10 anos). Possivelmente, quando o estigma da etnia começa a ser reconhecido pelas crianças ciganas, há uma tendência à rejeição da etnia de origem. Depois, a identidade étnica parece ser assumida, com todas as consequências daí resultantes, a começar pela do enclausuramento identitário, eventualmente associado a uma "auto-estima" (Monteiro, 2002).

A hipótese de investigação equacionada - e que merece estudos de maior fôlego empírico e analítico - sugere que as condutas rotuladas de "violentas" podem também ser efeito da aversão das crianças ditas violentas a uma escola que não sabe como as acolher nem como lhes incutir sentido de responsabilidade e disciplina. Nas escolas sentem-se em reclusão. O seu fechamento étnico ou identitário - assumido ou imputado - em nada ajuda a sua integração. O desafio que nos espera é o de desmascarar essas realidades, entre as quais se encontram formas ocultas de violência que, de tão subtis, nos passam despercebidas, embora se teçam nas tramas do cotidiano escolar.

\section{Referências bibliográficas}

ACTAS do Colóquio "Violência e indisciplina na escola". In: Colóquio Association Francophone Internationale de Recherche 
Scientifique en Education (AFIRSE), 11., Lisboa, 2001. Actas... Lisboa: Faculdade de Psicologia e Ciências da Educação da Universidade de Lisboa, 2001.

ANDERSON, Benedict. Imagined communities. Londres: Verso, 1991.

AUSTIN, John Langshaw. Cómo hacer cosas con palavras. Barcelona: Paidós, 1996.

BARTHES, Rolan. Mythologies. Paris: Paladin, 1972.

BATALHA, Luís. Contra a corrente dominante: histórias de sucesso entre cabo-verdianos da segunda geração. Etnográfica, v. VIII, n. 2, p. 297-333, 2004.

BOAL, Maria Eduarda de; HESPANHA, Maria Cândida; NEVES, Manuela Boralho. Educação para todos; para uma pedagogia diferenciada. Lisboa: Editorial do Ministério da Educação, 1996.

BOUDON, Raymond; BULLE, Nathalie; CHERKAOUI, Mohamed (Dir.). École et Société: les paradoxes de la Démocracie. Paris: Presses Universitaires de France, 2001.

BOURDIEU, Pierre. La jeunesse n'est qu'un mot. Questions de Sociologie, Paris: Minuit, 1980. p. 223-242.

; PASSERON, Jean-Claude. Les héritiers. Paris: Minuit, 1964.

CAIAFA, Janice. Movimento punk na cidade. A invasão dos bandos sub. Rio de Janeiro: Jorge Zahar Editor, 1989.

CLARKE, J. Subcultures, cultures and class. Working papers in Cultural Studies. Birmingham: Centre of Contemporary Cultural Studies, University of Birmingham, n. 7-8, 1976.

COHEN, Philip. Sub-cultural conflict and working class community. Working Papers in Cultural Studies, CCCS. Birmingham: University of Birmingham, n. 2, 1972.

COSTA, Maria Emíla; VALE, Dulce. A violência nas escolas. Lisboa: Council for International Exchange of Scholars (CIES), Institute of International Education (IIE), 1998.

DÁVILA, Oscar; GHIARDO, Felipe; MEDRANO, Carlos. Los desheredados: trajectórias de vida e nuevas condiciones juveniles. Valparaíso: Centro de Estudios Sociales (CIDPA), 2005.

DAYRELL, Juarez. A escola como espaço sócio-cultural. In: (Org.). Múltiplos olhares sobre educação e cultura. Belo Horizonte: Editora UFMG, 2001.

DURAND, Gilbert. Las estructuras antropológicas del imaginário. Madrid: Taurus, 1981.

ENGUITA, Mariano Hernandez. Escola e etnicidade: o caso dos ciganos. Educação, Sociedade \& Cultura, n. 6, 1996.

EWEN, Stuart. All consuming images. New York: Basic Books, 1988.
FONSECA, Maria Manuel Vieira. Educar herdeiros: práticas educativas da classe dominante lisboeta nas últimas décadas. Lisboa: Fundação Calouste Gulbenkian, 2003.

FOUCAULT, Michel. Os anormais. São Paulo: Martins Fontes, 2001.

GOFFMAN, Erving. A apresentação do Eu na vida de todos os dias. Lisboa: Relógio d'Água, 1993 [1. ed. em inglês: 1959].

HEBDIGE, Dick. Subcultures: the meaning of style. London/New York: Methuen, 1979.

JAVEAU, Claude. Éloge de l'élitisme. Tournai: Le Grand Miroir, 2000.

JEFFERSON, Tony. Cultural responses of the teds. In: HALL, Stuart; JEFFERSON, Tony (Eds.). Resistance through rituals. London: Hutchinson, 1976. p. 81-86.

LÉVI-STRAUSS, Claude. La voie des masques. Paris: Plon, 1979. LIÉGEOIS, Jean-Pierre. Minoría y escolaridad: el paradigma gitano. Madrid: Presencia Gitana, 1998.

MAGALHÃES, António M.; STOER, Stephen R. Orgulhosamente filhos de Rousseau. Porto: Profedições, 1998.

McLAREN, Peter. Rituais na escola: em direção a uma política de símbolos e gestos na educação. Rio de Janeiro: Vozes, 1992.

MERCER, Kobena. Black hair style politics. New Formations, n. 3, 1987.

MÓNICA, Maria Filomena. Os filhos de Rousseau. Lisboa: Relógio d'Água, 1997.

MONTEIRO, Maria Benedicta. A construção da exclusão social nas relações inter-étnicas: orientações teóricas e de investigação na perspectiva do desenvolvimento. [Texto policopiado em apoio a uma conferência realizada no ISCTE, abril de 2002.]

NIETZSCHE, Friedrich. On truth and lie in a extra-moral sense. In: KAUFMANN, Walter Kaufmann (Org.). The portable Nietzsche. New York: Vintage Books, 1980.

PACHECO, José. Sozinhos na escola. Porto: Profedições, 2003. PAIS, José Machado. Culturas juvenis. Lisboa: Imprensa NacionalCasa da Moeda, 1993.

Vida cotidiana, enigmas e revelações. São Paulo:

Cortez, 2003.

. Ganchos, tachos e biscates: jovens, trabalho e futuro. Porto: Ambar, 2005a.

. As múltiplas 'caras' da cidadania. In: CASTRO, Lúcia Rabello de; CORREA, Jane (Orgs.). Juventude contemporânea: perspectivas nacionais e internacionais. Rio de Janeiro: Nau Editora, 2005b. p. 107-133. 
PAIS, José Machado; BLASS, Leila Mari. (Coord.). Tribos urbanas. São Paulo: Annablume, 2004.

RUÍZ, Manuel Delgado. Cultura y parodia. Las microculturas juveniles en Cataluña. Cuadernos de Realidades Sociales, n. 4546, jan. 1995.

SEBASTIÃO, João. A produção da violência na escola. Relatório final de investigação. Lisboa: CIES, IIE, 2001. .; ALVES, Mariana Gaio; CAMPOS, Joana . Violência na escola: das políticas aos quotidianos. Sociologia, Problemas e Práticas, n. 41, p. 38-39, 2003.

SILVA, Maria do Carmo Vieira da. Ser aluno ‘negro' na escola da grande cidade: imagens de professores. Urbanitas. Revista de Antropologia Urbana, ano 2, v. 2, n. 1, p. 3, 2005. Disponível em: $<$ http://www.aguaforte.com/osurbanistas2/mariadocarmo1.html $>$. Acesso em: 23 mar. 2006.

SOUSA, Pastor José Pinto de. Entrevista. Boletim Informativo Príncipes do Nada, p. 4, jul. 2002.

SPRADLEY, James P. The ethnographic interview. New York: Rinehard and Winston, 1979.

TONG, Diane. Contos populares ciganos. Braga: Círculo de Leitores, 2002.
WHITIN, Phyllis; WHITIN, David. Inquiry at the Window: pursuing the Wonders of Learners. Portsmouth: Heinemann, 1997. Foram ainda usadas referências dos seguintes boletins periódicos portugueses: Boletim Informativo Príncipes do Nada, Diário de Noticias e Público.

JOSÉ MACHADO PAIS, doutor em sociologia, com agregação, é investigador coordenador do Instituto de Ciências Sociais da Universidade de Lisboa e professor convidado do Instituto Superior de Ciências do Trabalho e da Empresa (ISCTE). É coordenador do Observatório Permanente da Juventude Portuguesa, dirigindo várias pesquisas. Entre seus livros destacam-se: Culturas juvenis (Lisboa: INCM, 1993, 1995, 2003); Ganchos, tachos e biscates: jovens, trabalho e futuro (Porto: Ambar, 2001, 2003, 2005) e Nos rastos da solidão: deambulações sociológicas (Porto: Ambar, 2006). No Brasil, tem publicado Vida cotidiana: enigmas e revelações (São Paulo: Cortez, 2003).E-mail: machado.pais@ics.ul.pt

Recebido em outubro de 2007 Aprovado em novembro de 2007 


\section{Resumos/Abstracts/Resumens}

José Machado Pais

\section{Máscaras, jovens e "escolas do diabo"}

Um dos desafios da sociologia é o de desmascarar as actuações cotidianas, procurando descobrir o que elas revelam no que ocultam. De que forma? Pesquisando os usos que se fazem das máscaras. É esse o desafio que se lança, tomando-se como referenciais empíricos diferentes cenários de actuação das máscaras, a começar pelos actos de nomeação que mascaram a realidade a partir do momento em que a nomeiam. Será também dada atenção às máscaras que caracterizam os estilos juvenis e às tramas de significado que esses estilos escondem. Finalmente, questiona-se a existência das máscaras no cenário de escolas que retratadas como "escolas do diabo". Nesse caso, a hipótese discutida sugere que a violência protagonizada por alguns jovens nessas escolas é também uma máscara, dado ocultar formas subtis de violência a que esses jovens se encontram cotidianamente sujeitos.

Palavras-chave: juventude; violência escolar; identidades; máscaras

Masks, young people and "schools of the devil"

One of the challenges of sociology is to unmask daily happenings and to attempt to discover what they reveal by what they occult. This is possible by researching the uses that are made of masks. This is the challenge which we set ourselves taking as our empirical framework different scenes in which masks are used, beginning with acts of naming which mask the reality from the moment in which they are named.

Attention is also given to masks which characterize youth styles and to the intricate web of meanings which these styles hide. Finally, we question the existence of masks in the setting of schools portrayed as "schools of the devil". In the latter case, the hypothesis suggests that the violence which some young people are at the centre of in such schools is also a mask, given to hide subtle forms of violence to which these young people are daily subjected.

Key words: youth; school violence; identities; masks

Máscaras, jóvenes y “escuelas del diablo"

Uno de los desafios de la sociedad es el de desenmascarar las actuaciones cotidianas, procurando descubrir lo que ellas revelan en lo que ocultan. ¿De qué forma? Investigando los usos que se hacen de las máscaras. Es este el desafio que se lanza, tomándose como referenciales empíricos diferentes escenarios de actuación de las máscaras, comenzando por los actos de colocación que enmascaran la realidad a partir del momento en que la nombran. Será también dada atención a las máscaras que caracterizan los estilos juveniles y a las tramas de significado que esos estilos esconden. Finalmente, se cuestiona la existencia de las máscaras en el escenario de las escuelas que son retratadas como "escuelas del diablo". 
En este caso, la hipótesis discutida sugiere que la violencia protagonizada por algunos jóvenes en esas escuelas es también una máscara, ya que ocultan formas sutiles de violencia a la que esos jóvenes se encuentran diariamente sometidos.

Palabras claves: juventud; violencia escolar; identidades; máscaras 